Article

\title{
Sustainable Transitions Narratives: An Analysis of the Literature through Topic Modelling
}

\author{
Gianluca Stefani *(D), Mario Biggeri (1) and Lucia Ferrone
}

\begin{abstract}
Department of Economics and Management, University of Florence, 50127 Florence, Italy; mario.biggeri@unifi.it (M.B.); lucia.ferrone@unifi.it (L.F.)

* Correspondence: gianluca.stefani@unifi.it
\end{abstract}

Citation: Stefani, G.; Biggeri, M.; Ferrone, L. Sustainable Transitions Narratives: An Analysis of the Literature through Topic Modelling. Sustainability 2022, 14, 2085. https://doi.org/10.3390/su14042085 Academic Editor: Antonio Boggia

Received: 17 January 2022

Accepted: 10 February 2022

Published: 11 February 2022

Publisher's Note: MDPI stays neutral with regard to jurisdictional claims in published maps and institutional affiliations.

Copyright: (C) 2022 by the authors. Licensee MDPI, Basel, Switzerland. This article is an open access article distributed under the terms and conditions of the Creative Commons Attribution (CC BY) license (https:// creativecommons.org/licenses/by/ $4.0 /)$.

\begin{abstract}
A large and fast-growing field of studies, known as sustainability transitions, emerged at the end of the 1990s, relying on a number of theoretical approaches. Transition management, strategic niche management, sociotechnical transition and technological innovation systems are among the most popular frameworks used to theorize sustainability transitions, although other approaches have been used as well. Our research analyses a specific corpus of text composed of approximately 3500 abstracts of papers collected in the Scopus database related to the term sustainability transition with the help of machine learning techniques. We explore related subfields of this literature, both related to theoretical framework or sectoral focus and their evolution across years and publication outlets, depicting different sustainability narratives.
\end{abstract}

Keywords: sustainability transition; socio-technical transition; technological innovation system; topic modelling

\section{Introduction}

Policy makers, as well as social scientists, are paying increasing attention to the way societies may transit from the current to more sustainable modes of production and consumption [1]. This awareness requires fundamental transitions or transformations in core systems, entailing 'profound changes in dominant institutions, practices, technologies, policies, lifestyles and thinking' [2], and it urges deep structural transformations towards new ways of structuring our economies and production systems, a new social dynamic and more sustainable and inclusive forms of development. In other words, the transition requires a fundamental shift in the systems that fulfil societal needs in line with the Agenda 2030 ambitions and objectives embedded in the 17th Sustainable Development Goals (SDGs). Transitions and the related innovations can take place either at the country level or at the smaller regional level as is well documented in the case of the agri-food [3] or the energy sector [4]. Additionally, the role played by communities in the sustainability transition literature (see Section 3 below) adds to the relevance of the regional and local levels in the transition processes.

Whatever the geographical scale, the sustainability transition, as systemic change, involves multi-scalar processes of innovation, experimentation and learning or upscaling, as well as the replication or adaptation of new technologies or practices. Sustainability transition studies constitutes a field of research that is of high societal relevance, given the magnitude and pervasiveness of sustainability challenges that we are facing [1]. This literature emerged at the end of the 1990s relying on a number of theoretical approaches. Transition management, strategic niche management, socio-technical transition and technological innovation systems are among the most popular frameworks used to theorize sustainability transitions within the socio-technical perspective. Other perspectives have been used as well, such as the socio-ecological systems, socio-economic transformation or action-oriented ones [5]. 
The predominant framework adopted in the literature on socio-technical transitions to sustainability is the 'Multi-level perspective' (MLP). The core assumption is that transitions concern systems and the changes that happen within them [5]. The MLP adopts three fundamental analytical levels: niches, socio-technical regimes (STR), and the sociotechnical landscape [6]. Niches are the 'protected spaces' where radical innovations take place. Because of their fundamental role in the first phases of the transition (emergence and formative-EEA, 2018), they have a central role in the SST literature. The two main frameworks adopted in study niches are Strategic Niche Management (SNM)—see [7]), and Technological Innovation System (TIS)-see [8]. Socio-technical regimes are defined as the set of rules, institutions (including cultural norms) and practices consistent with dominant socio-technical structures. Socio-technical regimes are crucial in the transition process because they can hinder or promote change and progress. It is at the STR level that different types of lock-in can happen, whether economic lock-in, social lock-in or political lock-in. The economic and political lock-in can be strongly related when vested interests in current technology are tied to political power [5]. The socio-technical 'landscape' [9] represents the wider external context, composed of both slow-changing factors and sudden shocks [10]. The interaction between the landscape and the existing STR is what can create windows of opportunity for innovations. At the same time, the changes begun through innovation, once established in the STR, will affect the landscape.

The fundamental hypothesis of the socio-technical transition and the MLP is that:

'Transitions are not teleological and deterministic, but continuously enacted by and contested between a variety of actors. ... So, transitions are likely to be non-linear; two steps forward may be followed by one step back (or steps in a different direction if actors change their beliefs and goals or if there is growing contestation of particular pathways).' [11] (p. 900).

The continuous interaction of actors, and the different approaches from which it was born, make the literature around SST exquisitely multidisciplinary, which is well reflected in our analysis.

Differently from the socio-technical perspectives, the socio-economic one is focused on the role of market capitalism in influencing and determining human identity, values, norms and behavior. In particular this perspective posits that many sustainability challenges are driven by global market structures and norms such as consumerism and the work and spend cycle, which traps people in unsustainable practices. Socio-economic transformations are regarded as "co-evolutionary processes that include changes in modes of production, work relations and culture" [5] (p. 12). This perspective questions the ability of technological innovation alone to achieve sustainability goals without changing the dominant paradigms of the market system, hence the role played by social innovations such as local resilience and community-based initiatives.

Independently from the adopted perspective, transitions are also about the cultural discourse and the framing of problems and solutions [12], and therefore the nature of the research narrative will also be relevant. Narratives of change are ideas, concepts and metaphors which make up the discourse or the storylines concerning the transformation of society. Besides being a characteristics of research discourse [13], they are also a key ingredient of innovation initiatives [14] and individuals' courses of action [15]. The topics, issues and research problems tackled by scholars contribute to shaping the wider public opinion and consensus, therefore contributing to either upholding the socio-technical or socio-economic regimes or creating windows of opportunity for change.

We aim at exploring the subfields of this literature, either related to theoretical frameworks or to a sectoral focus depicting different sustainability narratives. Specifically, we aim to describe the major themes and their evolution across years and publication outlets, in a corpus of text consisting of abstracts of papers related to the sustainability transition literature, applying a quantitative text analysis technique on more than 3500 papers published in the last decade. 
As textual data grows, the ability of researchers to analyse these type of data declines because of the increasing time associated with the research process. Computational text analysis techniques, a branch of machine learning, are needed to process large amounts of text.

The availability of bibliographic databases provides researchers with huge numbers of textual data, often going beyond the capacity even of large research teams [16]. Topic modelling (TM) is a group of inductive techniques to discover key topics in a corpus of documents. TM automates such tasks through a statistical representation of textual data which models the probability of the co-occurrence of words within documents [13].

Our research analyzes a specific corpus of text composed of abstracts of papers collected in the Scopus database related to the term sustainability transition with the help of machine learning techniques.

Our aim is to identify the major research sub-fields, their dynamics and their related publication outlets in the sustainability transition literature. We innovate with respect to a previous quantitative literature survey by Markard et al. [1] regarding three respects. First, we focused on more recent years, characterized by a booming literature which, consistently with the auspices of Markard, has embraced new issues of power, politics and agency, as well as the role of civil society and cultural movements in transition processes [1]. Second, we employ machine learning techniques to automatically identify non-mutually exclusive topics or subfields in a large number of articles. Third, we relate topic prevalence with time and outlet of publication to study the dynamic changes in the literature and possible specializations of journals

According to the results, 13 topics were selected and then grouped into three main clusters of correlated topics: one on sectoral issues and related policies, one on social change needed to achieve sustainability transition with methodological aspects mainly of communities/participatory nature and one on innovation and institutional changes. Topic prevalence trends across years and possible specialization of outlet of publication by topic were also identified.

The paper is structured into four sections. In the second section, the technique of TM via machine learning is introduced. Then, following the procedure proposed in [1], methods and data are described. In the third section, results are discussed and the different clusters analysed, focusing on the most relevant papers. In section four, the main conclusions are given.

\section{Material and Methods}

\subsection{Topic Modelling}

The availability of bibliographic databases provides researchers with huge numbers of textual data. Summarizing and organizing the texts from this type of dataset is often beyond the capacity even of large research teams [16]. Topic modelling (TM) is a technique that automates such tasks through a statistical representation of textual data, which models the probability of the co-occurrence of words within documents [13]. More specifically, TM is a group of inductive techniques to uncover hidden topics in documents.

We define a collection of $\mathrm{N}$ documents as a corpus, the elements of each document being tokens, such as single words or a pair of adjacent words (bigrams). If $\mathrm{T}$ is the number of tokens in a language, a possible representation of the corpus is a (sparse) NxT matrix C, whose elements $c_{i j}$ are counts of the column token $\mathrm{j}$ appearing in the row document $\mathrm{i}$. As $\mathrm{C}$ is a high rank matrix, a lower rank representation of it provides a model of the structure of the textual data in the corpus. This lower rank representation can be approximated by a factor structure given by a set of $\mathrm{k}$ latent variables $\beta \mathrm{s}$, labelled as topics $[14,15]$. In other words, a topic is a distribution over a fixed vocabulary of tokens [16].

Topic modelling is a group of methods used to discover key topics in a corpus of documents. The structural topic modelling (STM) specification relies on an unsupervised generative model for text tokens whereby each counts vector $c_{i}$ is a draw from a fixed vocabulary of tokens, according to a token probability vector $\mathbf{q}_{\mathrm{i}}$ (document specific) and 
conditionally to the document length $\mathrm{m}_{\mathrm{i}}$ (in term of number of tokens). Then counts are distributed multinomial:

$$
c_{i} \sim \operatorname{MN}\left(q_{i}, m_{i}\right)
$$

with

$$
E\left[\frac{c_{i}}{m_{i}}\right]=q_{i}=\beta_{1} \theta_{i 1}+\beta_{2} \theta_{i 2}+\ldots+\beta_{k} \theta_{i k}
$$

where $\theta$ are topic weights and each latent variable $\beta$ represents a topic defined as a vector of probability over the vocabulary of tokens. Thus, the betas represent the contents of topics in terms of the co-occurrence of tokens (words), whereas the thetas measure topic prevalence in each document [15].

Topics and their weights are estimated resorting to Bayesian inference. STM draws the topic proportions (theta) from a logistic-normal linear model and the distribution over tokens from a multinomial [17]. This specification allows for general correlation patterns across topic proportions with respect to a popular alternative- the latent Dirichlet allocation-which impose strict independence. In addition, STM conditions the logisticnormal linear model on document-level covariates that may affect topic prevalence. Covariates help to investigate how frequently the different topics are discussed across a group of documents defined by structural characteristics (e.g., year of publication, type of source, authorship, etc.).

\subsection{Data Description}

To select the relevant literature, we follow the procedure proposed in [1], as well as implicitly following their definition of 'research on sustainability transitions' as comprising "all scientific articles that are concerned with the analysis of the institutional, organizational, technical, social, and political aspects of far-reaching changes in existing socio-technical systems (e.g., transportation and energy supply), which are related to more sustainable or environmentally friendly modes of production and consumption. Sustainability transitions research includes empirical studies, as well as conceptual and methodological contributions." [1] (p. 959). However, our paper is not just an update of the work by Markard. We share with [1] the definition above of sustainability transitions and the way we select from the Scopus database the papers to analyze by using the same keywords and carrying out the same two-step procedure to first identify seminal papers and then the papers they are cited by. However, we innovate by producing a deeper analysis of the content of the abstracts with the topic modelling technique, and we focus on post-2010 papers. On the one hand, the size of the recent literature would not have allowed the manual identification of topics pursued by [1], which was limited to the empirical focus of the articles (i.e., sectors of application). On the other hand, the small size of the pre-2010 literature would not have allowed a reliable estimation of the dynamic of topic prevalence across years.

We first searched the SCOPUS database for peer-reviewed articles that included the selected keywords in the abstract, title, or keywords fields. The research string used was:

TITLE-ABS-KEY ("strategic niche management" OR "technological innovation system" OR "technological system" OR "multi level perspective" OR "transition management").

The first string of research yielded 6305 results. Of these, we selected the first most cited 28 titles (see Table A1 in Appendix A, please note that most of these coincide with the list of [1]), excluding some that were obviously not dealing with socio-technical transitions and/or did not belong to the social-science area (i.e., engineering articles), or were obviously misplaced. We then searched for the records that included the title of these 28 papers in the references, and included another string of keywords, this time centered on sustainability terms:

TITLE-ABS-KEY ((sustainab* OR bio* OR renewable OR socio-technical) AND (transition OR transform* OR "system innovation" OR "radical innovation" OR shift OR change)).

We excluded documents in languages other than English, but initially included all types of documents; the search yielded 4840 results. The following Table 1 summarizes the 
corpus of abstracts thus defined. The vast majority are journal articles, followed by book chapters and reviews.

Table 1. Documents type and number.

\begin{tabular}{ccc}
\hline Document Type & Observations & Percent \\
\hline Article & 3747 & 77.42 \\
Article in Press & 1 & 0.02 \\
Book & 109 & 2.25 \\
Book Chapter & 334 & 6.90 \\
Conference Paper & 229 & 4.73 \\
Editorial & 30 & 0.62 \\
Letter & 1 & 0.02 \\
Note & 19 & 0.39 \\
Retracted & 1 & 0.02 \\
Review & 337 & 6.96 \\
Short Survey & 32 & 0.66 \\
\hline Total & 4840 & 100.00 \\
\hline
\end{tabular}

Source: Authors' elaboration.

For this analysis, we included only journal articles. Up to 2010, the sustainability transition literature was in its infancy, reduced in size (about 20 papers per year against 300 of the later period), with articles mostly published in a few journals and related to energy issues [1]. On these grounds, and to get more reliable estimates of the dynamic of topic prevalence, we discarded papers published before 2010 .

Our final corpus is therefore composed of 3524 abstracts.

Looking at the temporal distribution of papers, it is quite clear that there has been an exponential increase in later years, with few contributions before 2010 (Figure 1).

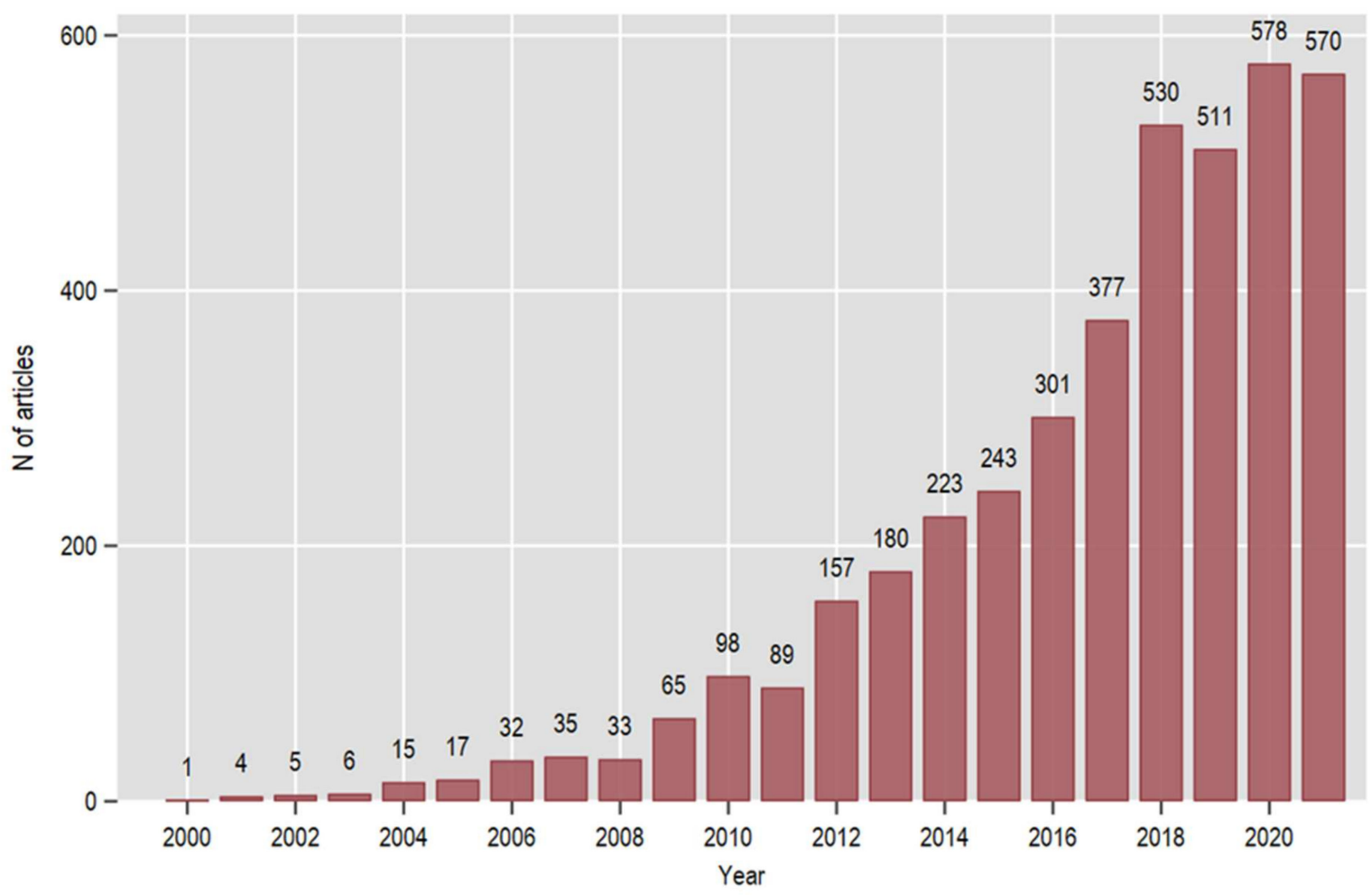

Figure 1. Number of documents by year. Source: Authors' elaboration.

The first step of the analysis is to preprocess the text by removing punctuation, numbers and common English stop words (such as articles, adverbs etc.). We also replaced all 
non-alphanumeric characters and chose to stem all words. Stemming allows us to consider in the analysis only the stem of a word, thus avoiding the treatment of terms such as price, priced, prices, pricing as different words. Afterwards, we analyzed the resulting bigrams to define a specific list of stop words (stemmed) to exclude from our corpus of abstracts. We tried to filter out common words used in the abstracts which could alter the topic analysis. In our case we dropped terms that were non-informative for our analysis, such as 'sustain' and 'transit'. The final list is composed of 87 words.

Considering the sources (i.e., journals) with at least 30 articles, we have 1864 articles, concentrated in 16 journals, which can be grouped into four broad topics, following the journals' topic classification provided by Scopus: management and control, ecology and geography, economics and social sciences. Sustainability is the journal with the overall largest number of articles, having increased its share of articles especially from 2016 onwards. The next most popular publication outlet is Environmental Innovations and Societal Transitions, a journal linked to the Sustainability Transition Network, created in 2009 (Figure 2), which ranked third in the first sub-period. Noticeably, energy policy, which was the most popular in the 2010-2015 period, now ranks only sixth, a sign of a shift of the literature towards outlets which accept papers from different disciplinary backgrounds.
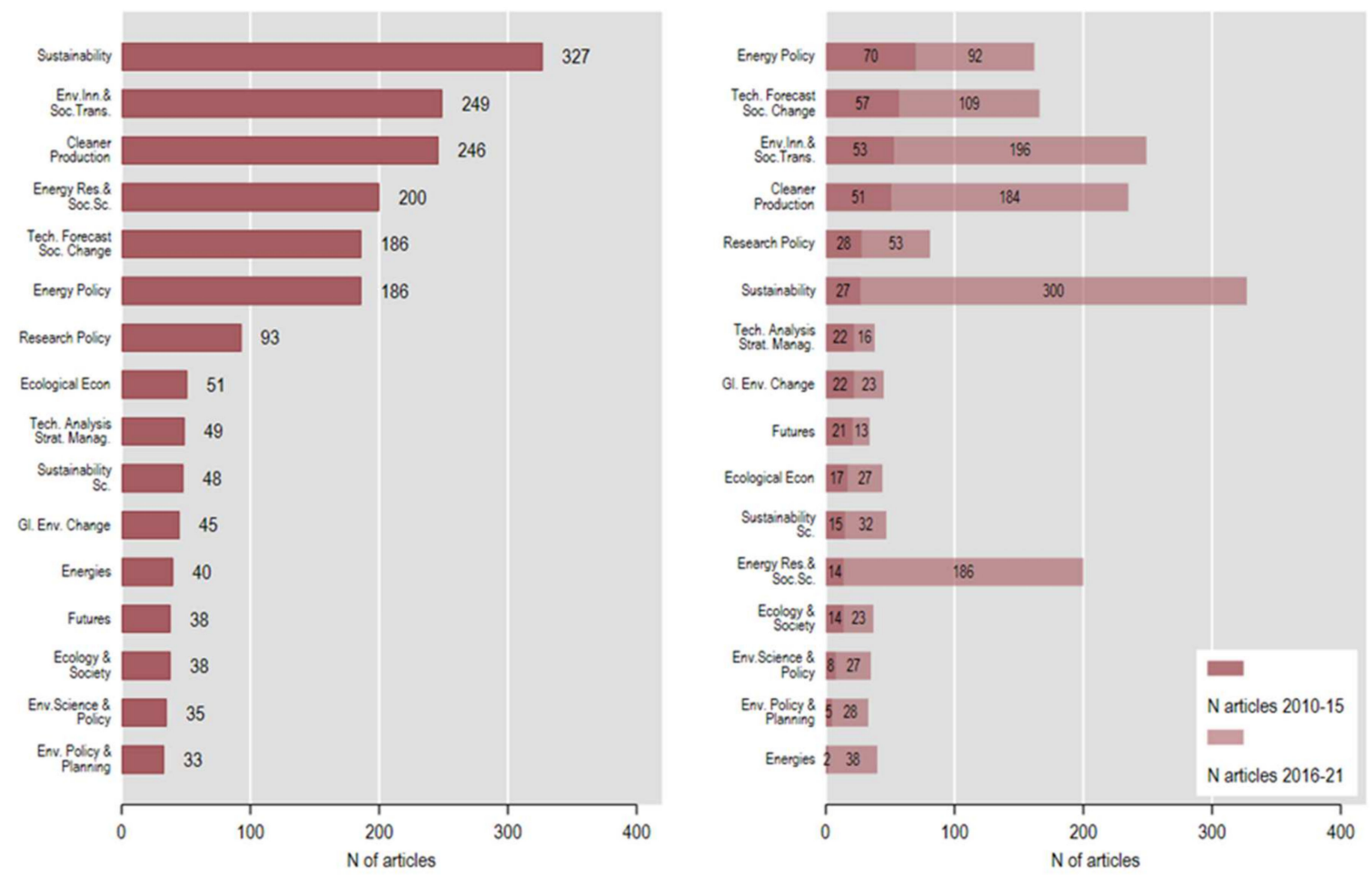

Figure 2. Number of articles by source and period (for sources with at least 30 articles in total). Source: Authors' elaboration.

\subsection{Model Choice}

The first step of the analysis is to define the number of topics. In order to do that, topics are classified according to their semantic coherence on one side and their exclusivity on the other. These categories define the main and opposite characteristics of the topics. Following $[17,18]$, the choice of the number of topics takes them into account, trying to balance between both.

The figure below (Figure 3) shows the distribution of the number of topics along these two dimensions; it is clear that a number of topics between 15 and 25 maximizes exclusivity, while 5 topics maximizes semantic coherence, sacrificing exclusivity. Focusing on a number of topics between 8 and 20, we identified 3 possible alternatives: 10, 13 and 15 (Figure 4). Figure 4 shows how many topics show higher than average semantic coherence 
and exclusivity (the red lines), both measures having been averaged across the three models $(10,13$ and 15 topics). We found that the number of 13 topics performs better in terms of balance between the two dimensions and substantive interpretability of results, however the three models were equivalent (Figure 4), so our final choice was mainly driven by interpretability.

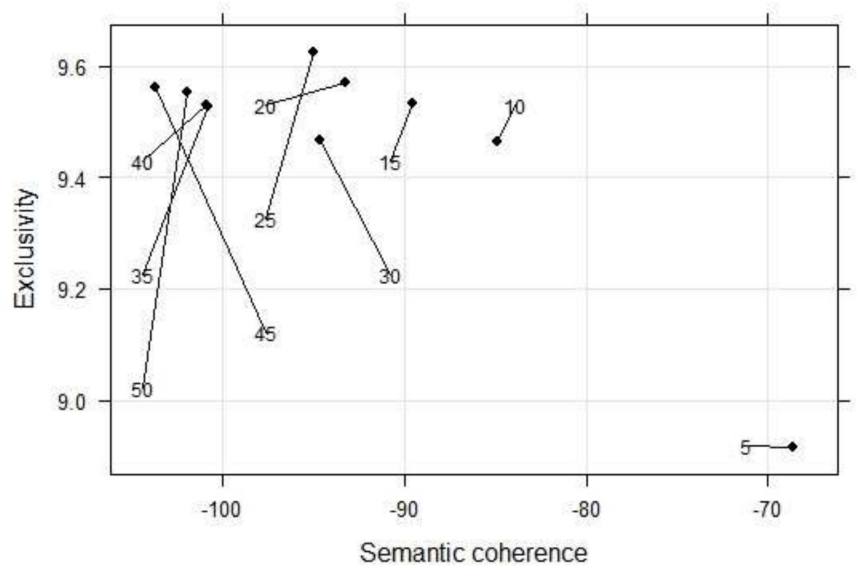

Figure 3. Distribution of number of topics according to exclusivity and semantic coherence. Source: Authors' elaboration.

10 Topics

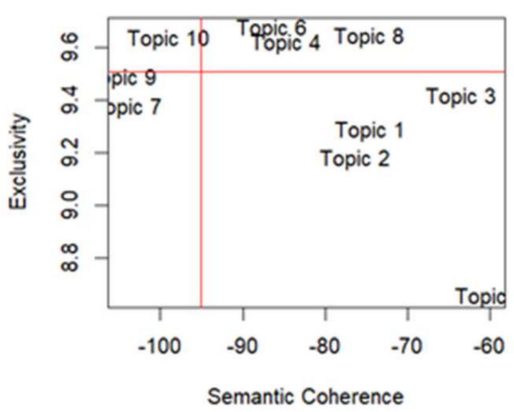

15 Topics

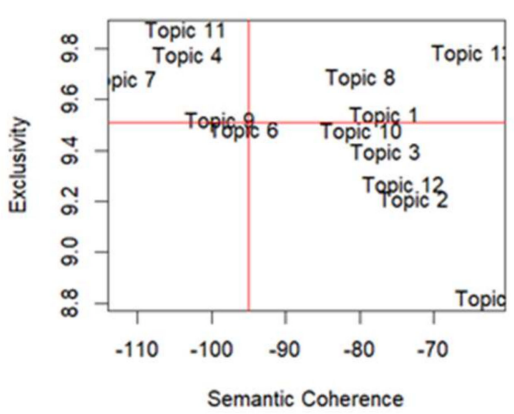

13 Topics

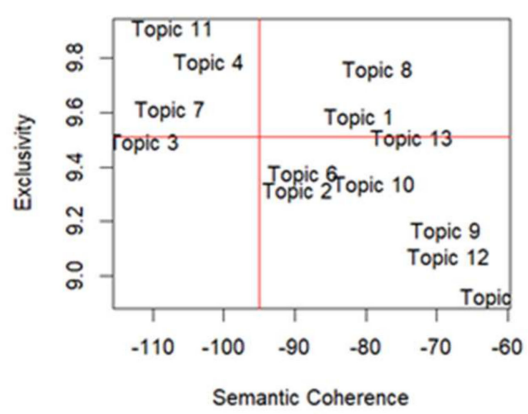

Figure 4. Semantic coherence and exclusivity of single topics in the three selected models. Source: Authors' elaboration.

The topic model was estimated using the stm package in R [17]. After having computed the topic model we estimated the effect of time and source (i.e., journal) covariate on the prevalence of topics. Finally, we computed topic correlation and graphed it using the igraph package in $\mathrm{R}$ developed by [19]. 


\section{Results}

The thirteen topics are summarized in Table 2, where the top seven stems for each topic are listed. The topics are ordered from the most to the least prevalent. We labelled the topics by looking at the most frequent words and the words more specific to the topic as identified by the FREX metrics [20]. The labels were then validated by inspecting the title and the abstracts of the ten documents with the highest prevalence of the topic. These are the abstracts where the words associated with the topics are more frequent.

Table 2. List of the most frequent and most specific terms in each topic and expected topic prevalence in the corpus.

Topic
1. Social Change and
Capitalism

2. Actors and Institutions

3. Methods

4. Innovation

5. Policy Mix

6. Communities

7. Decarbonization

8. Urban

9. Renewable Energy

10. Energy Policy

11. Food

12. Mobility

13. Water
Probability

Transform, social, chang,

understand, system, change, polit

Actor, socio-techn, institut, regim, role, case, nich

Develop, use, design, system, stakehold, can, manag Innov, technolog, model, develop, busi, new, network Polici, technolog, industri, system, innov, mix, develop

Local, social, initi, communiti, collect, group, individu

Climat, chang, carbon, emiss, technolog, develop, global

Urban, region, citi, develop, plan, experi, local

Electr, power, market, renew, energi, solar, wind

Energi, renew, polit, polici, system, nation, energy

Food, product, system,

agricultur, economi, circular, use

Transport, mobil, use, practic, chang, consum, consumpt Govern, water, green,

infrastructur, manag, system, chang
FREX

Resili, reflex, transformation,

transformations, social-ecolog, normat, scienc

Regim, actor, multi-level, mlp, institut, intermediari, agenc

Stakehold, tool, methodolog,

participatori, evalu, forest, method

Busi, innovation, innov, compani, innovations, network, model

Instrument, mix, tis, polici,

bioeconomi, industri, firm

Communiti, grassroot, initiatives,

rural, initi, communities, citizen

Emiss, mitig, carbon, climat,

greenhous, emissions, reduct

Citi, urban, experiment, region, spatial, cities, plan

Wind, solar, heat, grid, coal, electr, deploy

Energi, bioenergi, decentr, energy, bioga, germani, renew

Circular, farm, agricultur, food, agroecolog, farmer, crop

Car, mobil, user, mobility, vehicl, evs, behaviour

Water, govern, green, hous, infrastructur, australia, governance
Topic Prevalence

$12.7 \%$

$10.0 \%$

$9.9 \%$

$8.6 \%$

$8.0 \%$

$6.8 \%$

$6.5 \%$

$6.4 \%$

$6.4 \%$

$6.3 \%$

$5.8 \%$

Source: authors' elaboration.

Looking at Table 2, a general pattern is recognizable, with some topics being rather sectoral or thematic (topics 1 to 6 ) and others being methodological or theoretical (topics 7 to 13). This pattern is confirmed by the topic correlation analysis. Figure 5 shows three main clusters of correlated topics with circle sizes proportional to topic prevalence in the corpus. One cluster gathers the main sectoral topics revolving around energy issues and the policies that deal with these issues. A second one links the general issue of social change needed to achieve sustainability transition with methodological aspects mainly of a participatory nature, which explain the presence in the cluster of the communities topic. The third cluster links innovation with the actor and institution cluster. The latter is a topic about agency in socio-technical transitions, which is linked to the former because of the importance of the discourse about niche and networks of actors in the creation of new technologies, as posited by the multilevel perspective. Additionally, the food topic belongs to this cluster, possibly because several applications of the previous two topics have been carried out in the food sector. Finally, the urban and water topics form a small cluster because of the importance of water saving technologies in urban contexts, and the mobility 
topic stands alone given its socio-technical peculiarities. We provide a brief description of the three main clusters below.

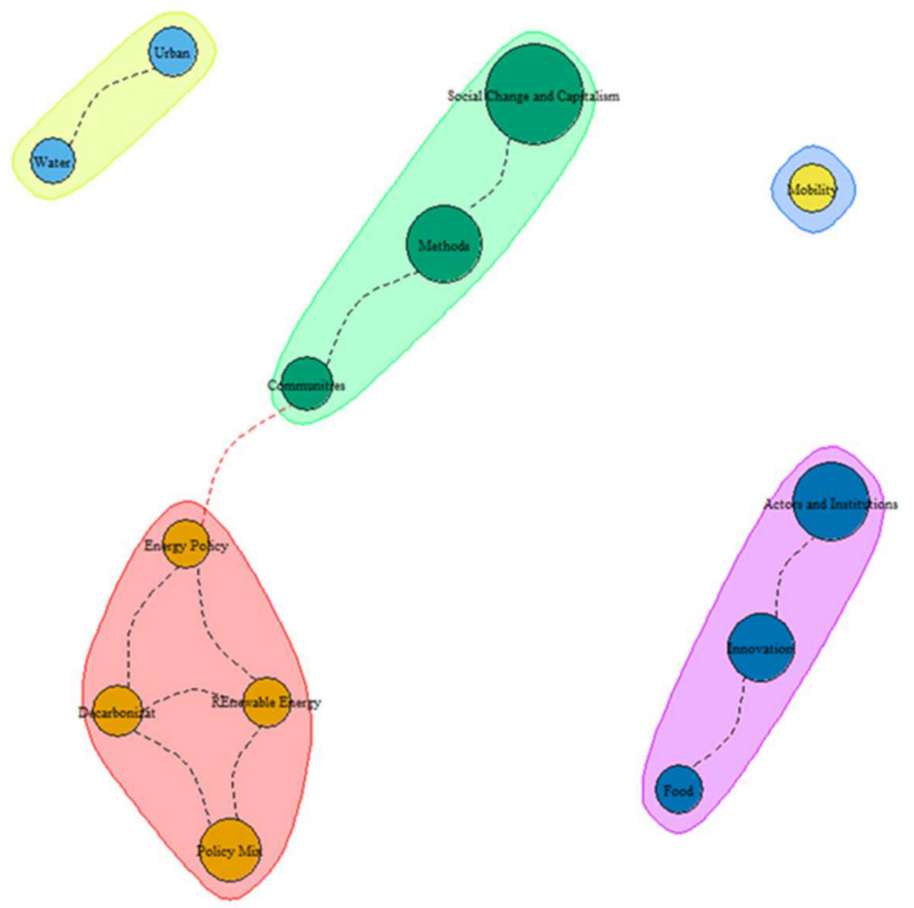

Figure 5. Topic correlation graph. Ties indicate correlations between topics higher than 0.01. Source: authors' elaboration.

\subsection{The Social Change and Capitalism Cluster}

Accounting for $29.4 \%$ of all topical content, the overarching theme of social change and capitalism cluster addresses the marketisation of society, social change and communities, as well as the participatory nature of the methods to study sustainability transitions, in line with the socio-economic nature of this cluster.

After the industrial revolution, the 'marketisation of society' emerged as the trait of capitalism that has led to unsustainable production and consumption practices. Societal changes that oppose this social trend need to address the role of the market in shaping human identity, values and behaviors [5]. Avelino [21], for instance, recognizes the role of "power over versus power to, centered versus diffused, consensual versus conflictual, constraining versus enabling, quantity versus quality, empowerment versus disempowerment and power in relation to knowledge" [21] (p. 1). Social change and economic perspectives are both needed together to create 'social foundations' for sustainability. Starting from the importance of environmental boundaries, this literature highlights a variety of social problems arising from societal traits such as materialism, consumerism, commodification and alienation, which hinder transformations toward sustainability [5].

Görg et al. [22] posit that a critical understanding of the challenges for societal transformations can be advanced by focusing on the interdependencies between societies and the natural environment. This also brings to the fore cultural immaterial aspects, such as values and a sense of place [23]. Woiwode et al. [24] put stress on the depth of this social change, which requires an inner transformation relating to various aspects of human existence and interactions such as consciousness, mindsets, values, worldviews, beliefs, spirituality and human-nature connectedness. This inner transformation-sustainability nexus is crucial to achieving a systemic change towards expanding human capabilities and sustainable development $[25,26]$. This implies the transition from a Shareholder capitalism towards a Stakeholder capitalism, moving to a global economy that works for progress, people and the planet [27]. 
According to Feola et al. [28], in order to foster sustainability transformations the societal change needs to reach beyond market capitalism:

"Theorizations of sustainability transformation have foregrounded the construction (making) of novel socioecological relations; however, they generally have obscured processes of deliberate deconstruction (unmaking) of existing, unsustainable ones. Amidst ever more compelling evidence of the simultaneous unsustainability and continued reproduction of capitalist modernity, it is misguided to assume that transformation can happen by the mere construction of supposed solutions, be they technological, social or cultural. We rather need to better understand whether and how existing institutions, forms of knowledge, practices, imaginaries, power structures, and human-non-human relations can be deconstructed at the service of sustainability transformation. This paper demonstrates the usefulness of a lens that attends to processes of making and unmaking in sustainability transformations through an analysis of an ongoing sustainability transformation, the territorios campesinos agroalimentarios (TCA) endogenous territorial figure and peasant movement in Colombia. TCA is transforming territory beyond capitalism on the basis of relational ontologies and principles of autonomy, dignity and sufficiency. This paper identifies processes of unmaking of capitalism in the TCA and demonstrates how they are concretely entangled in the construction of post-capitalist realities. This paper sketches a research agenda on sustainability transformation that is sensitive to and theoretically equipped for the analysis of transformation as a multifaceted, multilevel process that entails the deconstruction of capitalist modernity and the construction of post-capitalist realities. Central to this agenda is a plural engagement with theories of social change from across the social sciences and humanities, which have not previously been mobilized for this endeavour." [28] (p. 1)

In this direction, the socio-economic perspective complements the socio-ecological perspective's focus on environmental boundaries with an attention to the economic system and to the potential for social innovation to trigger change towards more socially and environmentally beneficial economic structures i.e., to a sort of place-based "shared capitalism". Moreover, in line with [29]—in the face of multiple crises of ecology, economy, and social equity - the question of how to democratically progress toward a more sustainable society is high on the political agenda as well as pertinent to academic research. At the same time, the research design and policy spaces increasingly recognize the importance of bottom-up actions at the community scale in responding to environmental challenges. Linking together community-level initiatives into networks, with the aim of achieving systemic and transformative change via participation, opens up the space for a democratic and non-paternalistic discourse on development visions, choices and strategies [30].

Mori and Tasaki [31] underline that the transformation towards sustainable social systems requires both individual and collective pro-environmental behaviors, bridging to the second topic about community actions. Ferguson and Lovell [32], analyzing communities of practices, highlight how grassroots networks and social movements are increasingly regarded as agents of change that can help respond to environmental degradation by both generating novel solutions to existing problems and influencing institutions towards more substantive responses. In particular, Community-based initiatives (CBIs) towards sustainability are increasingly relevant for sustainability transitions. Findings show that CBIs' public funding challenges, technical and procedural negotiations, goals and ways of working affect their community identity and aspirations [33]. New social practices emerge continually through the interaction of actions, materials, competencies and meanings. A good example of the involvement of communities in sustainability transition is given by Sloot et al. [34] regarding community energy initiatives in the Journal of Global Environmental Change. 
"Community energy initiatives can foster a sustainable energy transition by promoting sustainable energy behaviour in the communities in which they are embedded. This raises the question of what motivates people to become involved in these initiatives. We investigated the importance of financial, environmental, and communal motives for initiative involvement. We propose that communal motives (i.e., being involved in one's local community) may be related to initiative involvement, as community energy initiatives not only aim to promote sustainable energy behaviour but also enable people to be involved in their community. Across three studies, respondents rated financial and environmental motives as more important than communal motives for their involvement in community energy initiatives. Yet, environmental and communal motives were uniquely related to initiative involvement, while financial motives were not. The discrepancy between which motives people rate as important and which motives actually relate to their initiative involvement suggests that financial motives are an overrated motive, while communal motives are an underrated motive for involvement in community energy initiatives. Our results suggest that targeting communal motives may be an additional way to enhance involvement in community energy initiatives and foster sustainable behaviour among people, who may not otherwise be interested in environmental protection." [34] (p. 1)

Creamer and co-authors [35] underline, moreover, that the potential power of a community-based approach derives from the ability of community groups to tap into existing social networks and local bonds of trust to communicate messages and enact change.

The identification of an emerging strand of methodological inquiry in our literature databases is challenging. Quantitative analytical approaches to understanding systemic change, which contrast with and complement the conceptual frameworks on socioecological, socio-technical and socio-technical transitions, are nowadays complemented by a more participatory process of inquiry, to understand the complexity of interactions and relationships between biophysical systems (climate, ecosystems, global water and nutrient cycles, etc.) and key features of socio-economic systems. Nevertheless, Tourais and Videira [36] emphasize how the use of participatory modelling approaches in sustainability transition studies has been limited despite its potential contributions to transitions research.

Following Bohunovsky et al. [37], for instance, an integrated sustainability assessment (ISA) needs a participatory scenario development process.

"The paper discusses the role of visions within sustainability assessment and governance for sustainable development in Europe. Currently, our societies (still) develop along an unsustainable path, which results in a number of persistent problems (climate change, loss of biodiversity, poverty, etc.). Integrated sustainability assessment (ISA) is one approach designed to initiate transitions towards sustainability. Visions of a sustainable future form an important part of ISA. These visions support the process of discussing how the transition from today's societies/systems to a sustainable future can be achieved. According to the principles of ISA, visions should be developed in a participatory way, thus including the ideas and perceptions of stakeholders, decision-makers, experts and/or citizens. The paper starts with an introduction of the concepts of visions and scenarios and describes exemplary methods for their participatory development. Then, the main concepts for integrated sustainability assessment in comparison with other impact assessments are discussed. The main body of the paper presents experiences in three projects (ARTEMIS, ALARM, ECOCHANGE) in which visions and scenarios of sustainable futures were developed with stakeholders. The paper concludes with lessons learned and suggestions for future applications for participatory scenario development." [37] (p. 271) 
This literature emphasizes that, working towards sustainability transformation, requires involving professionals and stakeholders from all sectors of society into research and education for Sustainable Development [38,39]. This is in line with the idea proposed by Yunus et al. [25] on "Transformative Education and Research for Individual and Collective Learning Processes" whereby inducing a higher level of Sustainable Human Development in a society increases the society's capacity for the sake of a better sustainability transition..

\subsection{The Energy Cluster}

The Energy cluster (Policy Mix, Decarbonization, Renewable Energy, Energy Policy) is the second largest topic, with an overall prevalence of $27.2 \%$. The overarching theme of the cluster addresses the management and mitigation of climate change and of the energy transition, which are central pillars of the sustainability transition process. The main topic within this cluster is Policy Mix, which alone covers $8 \%$ of the abstracts, followed by Decarbonization. Indeed, two of the topics in this cluster relate to policy, remarking the centrality of policymaking for the transition. We also observe a link with the cluster related to social change and communities.

Policy mixes are mainly analyzed in their interaction with technological Innovation systems (TIS): how they can better support innovation towards sustainable transitions. Most of the examples and applications used are focused on energy and decarbonization (two of the other topics of the cluster). For example, Rogge and Schleich [40] examine the role of policy mixes in promoting low carbon innovations and analyze the transition towards renewable energy of the German electricity industry. In the same strain, Nykamp [41] analyzes the effect of policy mixes on innovations towards green buildings in the Norwegian construction industry.

One crucial aspect of policies is the link between their definition and their actual implementation. In this regard, Mavrot and co-authors [42] propose a conceptual framework to analyze policy mixes in the light of their outcomes, considering the context in which policies are implemented. Their abstract, reported below, illustrates their point.

“This article proposes the extension of a conceptual framework aimed at analysing policy mixes and their out-comes and demonstrates its value added for the study of sustainability transitions. The argument is that policy mixes research should not focus only on the form of policy instruments, but also on their implementation context. Policy mix form designates the specific policy instruments that are involved according to a policy strategy. Policy mix context includes the specific setting where each policy measure is implemented, such as enterprise or family. It also includes the specific target group of each measure, such as youth or smokers. We apply this conceptual framework to the policy concept and implementation of tobacco control policies in Switzerland, which are an exemplary case for analysing transitions as they are geared towards behavioural change. In a mixed method approach, we triangulate different sets of quantitative and qualitative indicators in order to assess the implementation of eleven subnational policy mixes. Our findings show that taking into account the moderating role of settings between policy instruments and target groups allows for a more in-depth analysis of policy processes. Observing the interactions between the four elements policy instruments, policy strategy, the implementation settings and the target groups allows capturing the complexity of policy mixes, at the crossroads of policy design, policy implementation and policy outcomes. Taking implementation settings and target groups into account in the analysis of policy mixes allows for a refined understanding of policy compliance and thus, from a broader perspective, of sustainability transitions." [42] (p. 1)

In the same vein, Hernández et al. and Edsand $[43,44]$ set out to expand the framework interlinking policy mixes and TIS. The former explicitly includes the economic actors upon which policies are enacted, to understand how the interaction between firms and policies 
leads to specific outcomes. The latter expands the TIS framework to include developing countries.

As mentioned, the literature on policy mixes is applied mostly to energy policy and to decarbonization, making clear the link between these topics. Although the topic of decarbonization has seen a decline over time (see Section 3.4), it is relevant both to the policy topic and the energy topics: the central role of governments and policy in supporting the transition is remarked on in several papers. Gota et al. [45] argue that a balanced mix of policies can support the decarbonization of the transport sector, while Lomax et al. [46] discuss the policies related to greenhouse gasses (GHG) abatement. Similarly, Ref. [47] argues the need to integrate GHG removal into the toolbox of emission control.

Goh et al. [48] analyze the drivers of the change in carbon composition of the electricity sector, concluding the need for stronger international cooperation in the promotion of renewable energy. Vergrat et al. [49], on the other hand, warn about the reliance on Carbon Capture and Storage (CCS) as, they argue, it can reinforce a 'fossil-fuel lock-in', preventing effective innovation. They stress the need for careful management of CCS TIS, as they illustrate in their abstract:

"Carbon capture and storage (CCS) is increasingly depicted as an important element of the carbon dioxide mitigation portfolio. However, critics have warned that CCS might lead to reinforced fossil fuel lock-in, by perpetuating a fossil fuel based energy provision system. Due to large-scale investments in CCS infrastructure, the fossil fuel based 'regime' would be perpetuated to at least the end of this century. In this paper we investigate if and how CCS could help to avoid reinforcing fossil fuel lock-in. First we develop a set of criteria to estimate the degree of technological lock-in. We apply these criteria to assess the lock-in reinforcement effect of adding CCS to the fossil fuel socio-technical regime (FFR). In principle, carbon dioxide could be captured from any carbon dioxide point source. In the practice of present technological innovations, business strategies, and policy developments, CCS is most often coupled to coal power plants. However, there are many point sources of carbon dioxide that are not directly related to coal or even fossil fuels. For instance, many forms of bio-energy or biomass-based processes generate significant streams of carbon dioxide emissions. Capturing this carbon dioxide which was originally sequestered in biomass could lead to negative carbon dioxide emissions. We use the functional approach of technical innovations systems (TIS) to estimate in more detail the strengths of the niches CCS and Bio-Energy with CCS (BECCS). We also assess the orientation of the CCS niche towards the FFR and the risk of crowding out BECCS. Next we develop pathways for developing fossil energy carbon capture and storage, BECCS, and combinations of them, using transition pathways concepts. The outcome is that a large-scale BECCS development could be feasible under certain conditions, thus largely avoiding the risk of reinforced fossil fuel lock-in." [49] (p. 282)

The topic of Renewable Energy is strictly linked to that of decarbonization; the most interesting contribution to this topic is the work of Mathews [50]. He addresses the transition to renewable energy from a theoretical point of view, arguing that the increasing deployment of renewable energy outlines a shift in the technological paradigm. He argues that the discussion around the energy transition has been dominated by neo-classical approaches, focusing on markets and stuck in the paradox of a 'carbon lock-in', described above. He argues for the need for a change in the terms of discussion in order to achieve effective change:

"Despite discussion of a 'carbon lock-in' and techno-institutional barriers to change, energy studies have had little serious contact with neo-Schumpeterian theorizing on technological 'surges' of creative destruction, which have characterized the entire industrial era from the 1770s on. In this paper a way is offered to link the current surge in renewable energy investment to the theorizing over 
long (Kondratiev) waves and techno-economic paradigm shifts. The paper argues that the current renewable energy surge can be best comprehended as a secondary surge in the fifth long K-wave, coinciding with the shift from gestation to installation of a new sixth techno-economic paradigm within the matrix of the fifth. It is argued that this emergent 6th paradigm is a continuation and fulfilment of the 5th, where IT and ICT are applied to the electric power grid, and that both are in conflict with the still-incumbent 4th paradigm based on fossil fuels and centralized power generation. The emergent 6 th paradigm is driven by the technology surge associated with renewable energies, particularly in China where the investment is most intense and the falling costs are driving market expansion. It portends a renewable energy speculative financial boom and bubble which could burst sometime in the period 2015-2020, ushering in a period of sustained development of renewables and energy-efficiency services by productive rather than financial capital." [50] (p. 10)

Most of the other papers in this topic discuss specific technology adoption and its promotion through policy, while warning of potential pitfalls. Chen et al. [51] investigate the overseas energy investment of the United States, Japan, and China, and find that most of them are fueling a carbon lock-in, financing fossil-fuel plants in developing countries. $\mathrm{Li}$ et al. [52] investigate the renewables market in Japan, finding how the solar lobby has prevented investment in wind energy. Norberto and co-authors [53] discuss the factors affecting photovoltaic deployment, while Csereklyei et al. [54] reflect on the energy transition in Australian's energy market. Pai and colleagues [55] address the important question of job losses tied to the energy transition, suggesting that the solar sector has more potential to absorb jobs and ensure a 'just transition'.

The theme of just transition and the public perception of the energy transition are central in the topic of Energy Policy. Healy and Berry [56] discuss the need for a more systematic debate on the politics and power dynamics at place in the energy transition, and especially in fossil fuel divestment. In particular, they highlight the central role of labor, thus connecting with [55], cited above. Williams and Doyon [57] analyze the case of the Energy Futures Lab to investigate the concept of justice in transition, arguing that the focus on 'winners and losers' of the transition is limited, and justice should be ensured in the process as well as in the outcomes

Several papers then discuss the public perception around energy transition and climate change. Lyytimaki and colleagues $[58,59]$ analyze the news coverage related to biogas; Antal et al. [60] reflect on the perceptions around the German energy transition. Haukkala [61] studies the formation of a green transition coalition in Finland, finding that effective advocacy is hindered by the different views of the actors.

\subsection{The Innovation Cluster}

Overall, the innovation cluster (Innovation, Actor and Institutions and Food) has a prevalence of almost $25 \%$ across the corpus. Within the cluster, the innovation topic accounts for almost $7 \%$ of topical content. This is not surprising as innovation is a key ingredient of the transition process. However, its prevalence has been declining in the last ten years, as we will show below. This topic mostly deals with the organizational rather than technical components of innovation. Business models more apt to promote sustainable innovation are analyzed with a specific focus on collective arrangements under the form of joint business models, alliances, networks or clusters $[4,62,63]$. A systemic view is prevalent with theoretical references to the multilevel perspective on socio technical transitions and the innovation system approach [64]. The role of niche strategic management in creating the environment for innovative projects to unfold is also stressed, with a central role played by learning in its different forms [65]. Strategic literature is recalled to frame the way collaborative networks or industry clusters create the supportive environment for their sustainable innovative technology to develop. Notably, network firms strategically engage in processes and activities revolving around key issues such as technology development, 
market creation and socio-cultural change. The abstract of Planko et al. [4] is an illustrative example of this topic:

"The implementation of innovative sustainability technologies often requires farreaching changes of the macro environment in which the innovating firms operate. Strategic management literature demonstrates that the chances of a successful diffusion and adoption of an innovative technology in society are increased if the firms wanting to commercialize this technology collaborate in networks or industry clusters to build a favourable environment for their technology. However, the strategic management literature does not offer advice on how to strategically create this supportive external environment. We fill this gap with complementary insights from the technological innovation systems literature. We introduce the concept of strategic collective system building; this concept describes processes and activities that networks of actors can strategically engage in to collectively build a favourable environment for their innovative sustainability technology. Furthermore, we develop a strategy framework for collective system building. To underpin our theoretical analysis empirically, we have conducted a case study in the Dutch smart grid field. The resulting strategy framework consists of four key areas: technology development and optimization, market creation, socio-cultural changes and coordination. Each of these key strategic areas is composed of a set of system-building activities." [4] (p. 2328)

As the collective and systemic nature of innovation is underlined, the innovation topic is linked with the one on "actors and institutions", which are, respectively, the subjects of and the framework for the collective innovation efforts. This is the second most prevalent topic of the corpus, as it accounts for $10 \%$ of the contents with a positive trend in the last decade. The sociological concept of agency is used here to understand the destabilization and the disruption of socio technical regimes, again within a multilevel perspective. Kuokkanen et al. [66] is a representative paper showing how actors use their agency to actively shape the selection environment for niches to evolve:

"The growing urgency of environmental threats combined with the slow pace of sustainability transitions has turned attention towards a better understanding of regime destabilization. Focusing excessively on niche innovations could be incumbent regimes' diversion and resistance strategy and could reinforce the "business as usual" mindset instead of contributing to system-wide changes. Historical cases of system transition have most often been used to understand the dynamics of regime destabilization. However, these insights have limitations when the focus is on ongoing transitions. Moreover, it is argued that more attention should be paid to agency and actors. Herein, regime destabilization is understood through an internally structured selection environment, implying that agency is assumed not only in variation at the niche level but also in the selection processes: (1) the selection environment is shaped by active and strategic actors and actor networks; (2) the selection environment is shaped by diverse discursive framings; and (3) the selection environment is shaped by various actors beyond the regime and even beyond the system in question. The argument is empirically tested in the case of the Finnish food system by constructing prevailing storylines in the sustainability transition. Four contrasting but partially overlapping storylines and their associated actor networks are identified. The empirical case supports the view that actors across all levels aim to influence the selection environment's formulation with their framing of the problem and the strategic response. Thus, more attention must be paid to the content and diversity of different discursive framings in sustainability transitions." [66] (p. 1513)

Other papers $[67,68]$ focus on institutional work practices to transform institutions and change the incumbent regime, the presence of alternative institutional logics being a prerequisite for regime disruption [69]. Issues of power and legitimacy are also recalled 
as they help to explain how incumbent socio-technical systems delay sustainability transitions through strategies of resistance and accommodation. Parts of the conflict between incumbent actors and those supporting innovation runs through the building of different social representations, or narratives, of novelty [70], as the reproduction of socio-technical regime impinges on power exerted in material, institutional and discursive forms [71].

Although thematic, the food topic shares with the innovation topic the attention to the collective nature of actions and practices leading to innovation [72,73]. Technical, institutional and economic barriers or lock-ins and ways to overcome them are discussed in Meynard et al. [74] and Messner et al. [75]. Diversification of farming system either from the agronomic or socio-economic point of view is a key element of transitions [76,77]. Agroecological transitions are an application of the multilevel perspective to the food system. Here, transition stages are employed as analytical tools to understand the development of transition strategies within the efficiency, substitution and redesign (ESR) model, as illustrated by Lamine and co-authors [78].

"The growing criticism of intensive agricultural practices that lead to a deterioration of natural resources and a decrease of biodiversity has progressively led to more environmental constraints being put on agricultural activities through an ecologization of agricultural policies. The aims of these policies have been to protect environmentally sensitive areas, to improve groundwater quality and, more recently, to develop organic farming and/or reduce pesticide use. However, these efforts are still a far cry from a robust ecologization of agricultural practices. In order to identify the conditions for the implementation of such an ecologization, the changes in practices from conventional agriculture towards organic farming and integrated pest management (IPM) are investigated using a sociological study of farmers' trajectories, coupled with the ESR (Efficiency-Substitution-Redesign) framework developed by biological and agricultural scientists. This combined approach reveals that a robust ecologization of agricultural practices requires us to take into account the specific and variable tempo of farmers' trajectories and to redesign not only technical agricultural systems but also interactions within larger agrifood systems." [78] (p. 209)

\subsection{Trends in Topics}

A further dimension of analysis investigates how topic prevalence in the corpus varies with time. Figure 6 shows the trends in topics by cluster. In the Energy cluster, topics related to policy (both mixes and energy) have increased over time, as well as the topic of renewable energy, while decarbonization has seen a marked decrease over time. These trends highlight a shift in the energy transition narrative, which moved towards a broader focus, addressing socio-political as well as technical aspects. Similarly, the innovation cluster sees an increase in the topics of actors, institutions and food, and a decrease in the topic of innovation. The increase in the food topic reflects the increasing concerns towards sustainable food production and food security, while the increase in the topic of actors and institutions highlights, again, a shift toward the more socio-political aspects of the transition. The Social change and capitalism cluster sees an increase in the topic of communities and a decrease in the topic of social change and capitalism, while methods remain the same. Finally, the remaining topics see a sharp decrease in the topic of water, a stable presence of mobility, and a slight increase in the urban topic. These trends outline how the narrative of socio-technical transitions has changed, both through a shift in focus and in language. Over the past ten years, research around sustainability transitions has moved towards an approach more centered on energy transition and policies on one side, and on the central role of institutions and actors on the other. Furthermore, there is an increased attention paid to the role of communities and political actors, with respect to a broader, systemic approach. These changes reflect in part the changes in political priorities and public discourse, for example, the attention given to the topics of sustainable energy and communities in the Agenda 2030. 

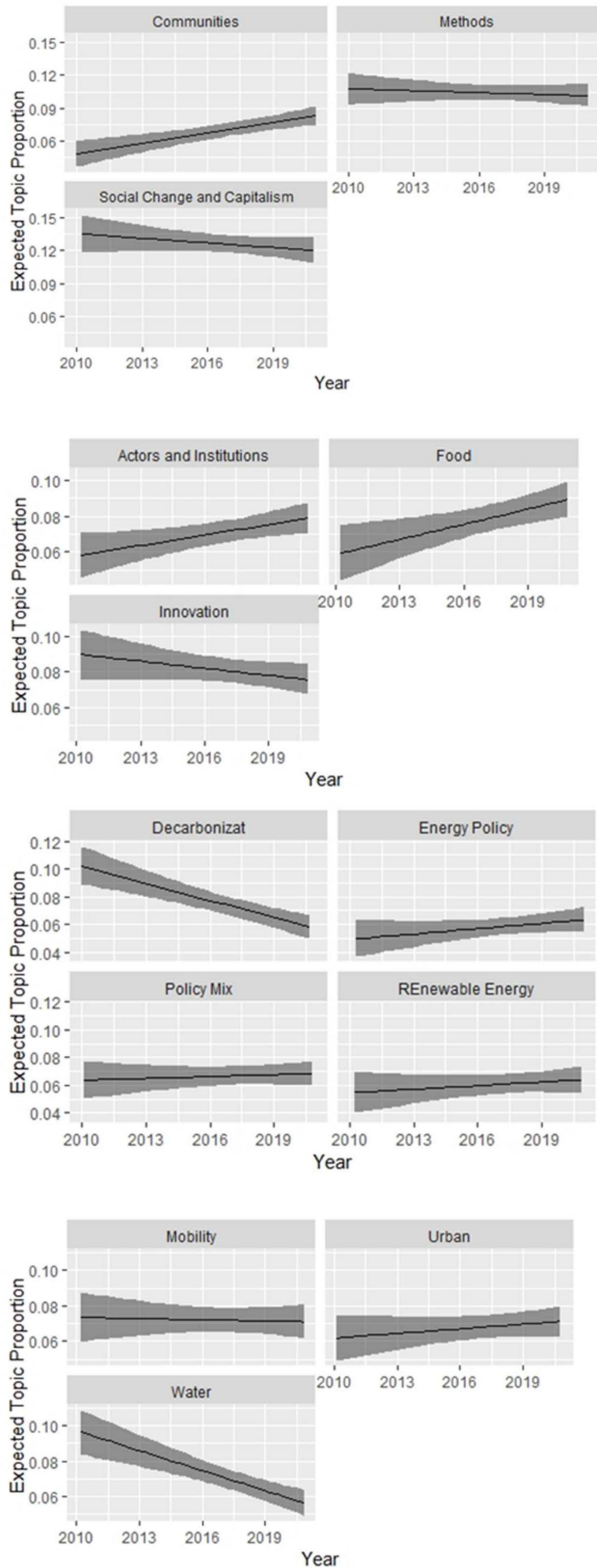

Figure 6. Trends in topic prevalence, 2010-2020.

\subsection{Topics' Prevalence in Sources}

The last decade has also seen an increasing importance of food systems in the transition literature. Other topics have remained stable over time, confirming their importance, such as policy mix and innovation. Some of the trends may seem counter-intuitive, such as 
that of decarbonization, however some of them can also be driven by a shift in language, highlighting a change in narrative. This topic has likely been absorbed by the increasing research in energy (both policy and renewable). Similarly, the slight decrease in innovation has likely been derived from the increase in institutions and policy mixes, as research has shifted towards addressing their key roles in driving innovation.

Another dimension of analysis is about conditioning topic prevalence in outlets of publication. Topics are well distributed across the main journals analyzed (Figure 7), showing how research on socio-technical transition is inherently multidisciplinary. Sustainability confirms its central role as a multidisciplinary outlet, with articles distributed across all topics. Some of the sources are clearly more specialized: Technology analysis and Strategic Management papers are more likely to be about the topic of innovation, while Research Policy papers are more likely to deal with Policy Mix. Methods and Social Change are mostly addressed by papers in Sustainability Science. In general, the prevalence of topics across journals is fairly similar, with notable exceptions for the social change and capitalism, actors and institutions and policy mix topics, where the prevalence figures appear more dispersed across journals.

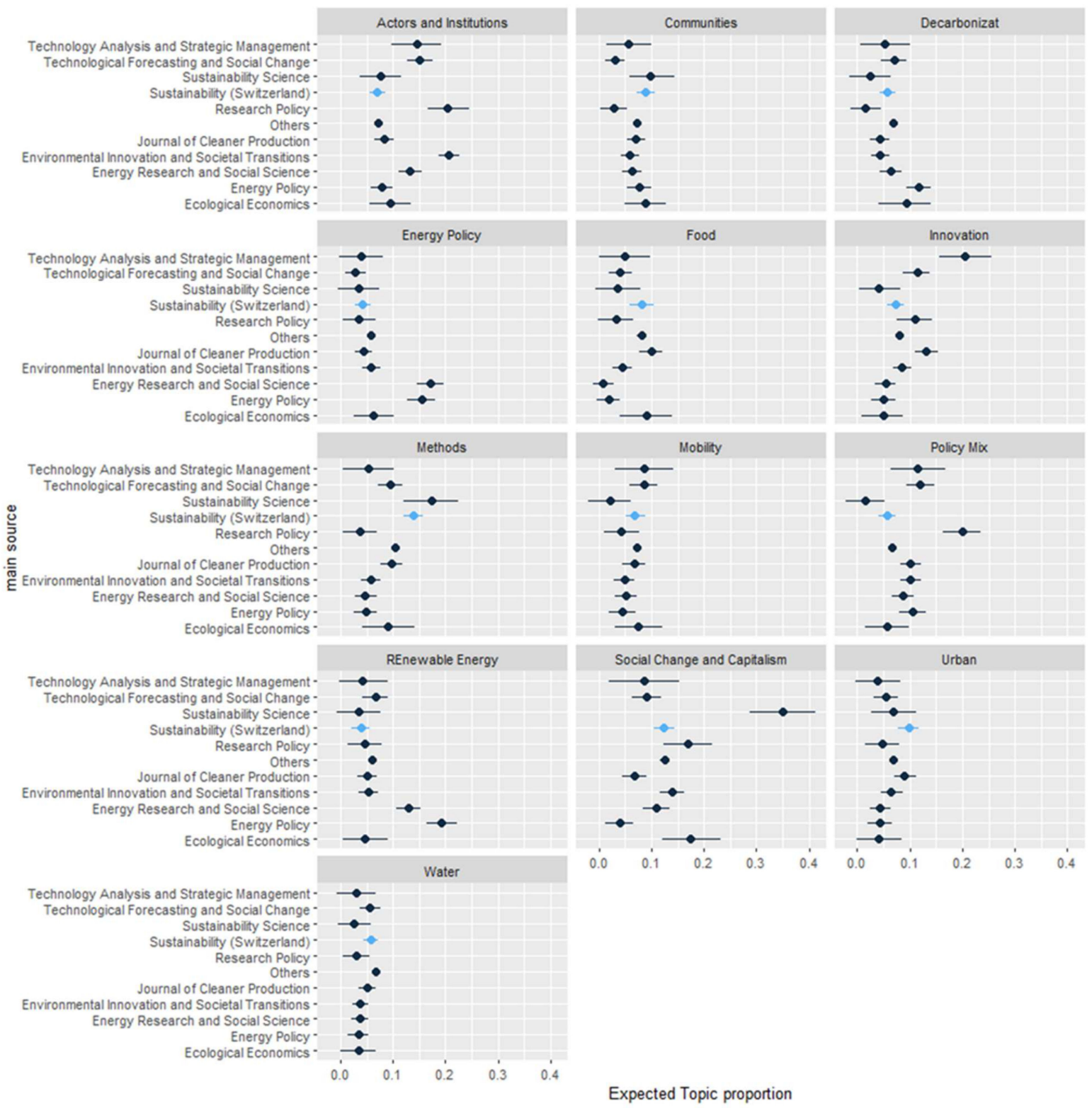

Figure 7. Proportion of topics across main sources. 


\section{Conclusions}

The results of this study, first of all, confirm that the field of research into sustainability transition studies has boomed in recent years, with a huge and steep rise in the number of papers and book chapters published, as well as the involvement of a number of new multidisciplinary publication outlets. The previous review by Markard and co-authors found only about 480 papers on the theme up to 2011, albeit with slightly different criteria [1], while our review covers more than 3000 articles in the last decade. This field of the 4 top journals identified in [1] now only accounts for $15 \%$ of all articles, with a dramatic change in the journal rankings in terms of number of published articles. The former top journals-Energy Policy, Technological Forecasting and Social Change, Technology Analysis and Strategic Management, and Research Policy-have been completely replaced by new journals: Sustainability, Environmental Innovations and Societal Transitions, Journal of Cleaner Production and Energy Research and Social Science. Conversely, the empirical topics which receive attention have remained mostly the same as those highlighted by [1]: energy, transportation, water and food. However, this application of topic modelling highlights new features of the sustainability literature, discovering not only empirical topics but also theoretical and methodological ones, drawing on the co-occurrence of words within abstracts.

According to our topic model, there are three main dimensions of the sustainability transition literature: one is social and capitalism change, behaviors and values; one is innovation and institutional changes and one is policy and societal core functions. The last two dimensions can be collocated within the socio-technical perspective on sustainability transition, while the first one refers to the socio-economic transformation perspective.

The "social and capitalism change, behaviors and values" dimension considers the increasing individual and collective awareness of sustainability transition. This dimension highlights the passage to a "stakeholder capitalism" (vs shareholder capitalism) as well as the effects of our behaviors on sustainability transitions. It also deals with the diffusion of innovative solutions and processes among all people, actors (public, private and social) and places. We can place this dimension within the broader perspective of socio-economic transformations [5], with its focus on the marketisation of contemporary societies and its impact on the possibility to achieve sustainability goals at the societal level. Noticeably, a local or regional dimension is also present with the topic of communities and their role in sustainability transitions.

The "innovation and institutional changes" dimension, conceived as the search for new solutions, new technologies, new materials, etc. (including rediscovering past and often environmental-friendly practices and solutions) to tackle societal challenges and expand human capabilities today and in the future, highlights the institutional changes needed to accompany the transition at both country and regional scales. This dimension is consistent with the multilevel perspective on sociotechnical transitions [6], with its focus on the interplay of technical, social and institutional aspects which affect the possibility to achieve systemic changes through sustainable innovations.

The "policy and societal core functions" dimension provides knowledge for evidencebased policymaking in energy, water, mobility and food for advancing material flows management and improving conditions for individual and collective actions towards sustainability. These sectors can be conceptualized as socio-technical systems, again within the multilevel perspective, which "addresses stability and change in the systems that perform core functions for society (e.g., providing energy, mobility, housing) but also account for most of humanity's pressures on the environment" [5] (p. 10).

In a sense, the auspices made by Markard [1] ten years ago have been at least partially fulfilled. The call for a better understanding of "politics and policies of sustainability transitions" highlighting "issues of power and politics" [1] (p. 962) has found an answer in the large prevalence of the topics within the social change and capitalism cluster. Additionally, "the role of civil society and cultural movements in transition processes" has been increasingly addressed within the same cluster, notably by papers dealing with the community 
topic. Similarly, the need to "better understand the long-term impacts of specific policies on sustainable transition" has been addressed within the policy mix topic.

Thanks to the application of topic modelling, we were able to uncover the abovementioned dimensions and discover quantitative patterns in the literature that may have gone unnoticed, such as the different prevalence of key topics and how their importance changes over time and across publication outlets. Our main findings both in terms of topic clusters or broader subfields of the literature and in terms of temporal patterns and trends of the different topics provide a bird's eye view of the evolution of the literature on sustainability transitions, a literature which is moving towards an approach more centered on energy transitions on one side and on the central role of communities and political actors on the other. In addition, our study of the relationship between topic prevalence and outlet of publication provides a map that can be also very useful for potential authors to select potential journals where a paper can be submitted, especially for those topics where a marked differentiation across journals emerged.

Topic modelling also opens up opportunities for future research in sustainability transitions such as the identification of under-explored areas in the field. For example, the clustering of topics shows that the innovation topic is mostly connected on the one hand with the food empirical topic and on the other hand with the actor and institution topic, posing the question of whether sustainability transitions in the food sector are inherently different from transitions in other sectors, and more generally whether sector specificities may affect the way transitions are studied. Further improvement of our analysis may concern the use of additional metadata such as citations to measure the prestige associated with key topics or the geographical location of authors to investigate the presence of geographical specificities in the literature.

Author Contributions: Conceptualization, G.S., M.B. and L.F.; methodology, G.S.; validation, M.B.; data curation, L.F.; writing—original draft preparation, G.S., M.B. and L.F.; writing—review and editing, G.S., M.B. and L.F. All authors have read and agreed to the published version of the manuscript.

Funding: This research received no external funding.

Institutional Review Board Statement: Not applicable.

Informed Consent Statement: Not applicable.

Data Availability Statement: Restrictions apply to the availability of these data. Data was obtained from Elsevier and are available at https:/ /www.scopus.com (accessed on 2 November 2021) upon subscription.

Conflicts of Interest: The authors declare no conflict of interest.

\section{Appendix A}

Table A1. Seminal papers used to identify the corpus of abstracts.

\begin{tabular}{ccccc}
\hline No & Title & Authors, Year, and Journal & Citations & Markard et al., 2012 \\
\hline 1 & $\begin{array}{c}\text { Technological transitions as } \\
\text { evolutionary reconfiguration } \\
\text { processes: A multi-level } \\
\text { perspective and a case-study } \\
\text { Typology of sociotechnical } \\
\text { transition pathways } \\
\text { From sectoral systems of } \\
\text { innovation to socio-technical } \\
\text { systems: Insights about } \\
\text { dynamics and change from } \\
\text { sociology and institutional } \\
\text { theory }\end{array}$ & $\begin{array}{c}\text { Geels F.W., 2002, Research } \\
\text { Policy }\end{array}$ & $\begin{array}{c}\text { Geels F.W., Schot J., 2007, } \\
\text { Research Policy }\end{array}$ & Geels F.W., 2004, Research \\
Policy & Yes & Yes \\
& & 1743 & Yes \\
\hline
\end{tabular}


Table A1. Cont.

\begin{tabular}{|c|c|c|c|c|}
\hline No & Title & Authors, Year, and Journal & Citations & Markard et al., 2012 \\
\hline 4 & $\begin{array}{l}\text { Regime shifts to sustainability } \\
\text { through processes of niche } \\
\text { formation: The approach of } \\
\text { strategic niche management }\end{array}$ & $\begin{array}{c}\text { Kemp R., Schot J., Hoogma } \\
\text { R., 1998, Technology } \\
\text { Analysis and Strategic } \\
\text { Management }\end{array}$ & 1499 & Yes \\
\hline 5 & Understanding carbon lock-in & $\begin{array}{c}\text { Unruh G.C., 2000, Energy } \\
\text { Policy }\end{array}$ & 1404 & Yes \\
\hline 6 & $\begin{array}{c}\text { Functions of innovation systems: } \\
\text { A new approach for analyzing } \\
\text { technological change }\end{array}$ & $\begin{array}{l}\text { Hekkert M.P., Suurs R.A.A., } \\
\text { Negro S.O., Kuhlmann S., } \\
\text { Smits R.E.H.M., 2007, } \\
\text { Technological Forecasting } \\
\text { and Social Change }\end{array}$ & 1218 & \\
\hline 7 & $\begin{array}{l}\text { The governance of sustainable } \\
\text { socio-technical transitions }\end{array}$ & $\begin{array}{c}\text { Smith A., Stirling A., } \\
\text { Berkhout F., 2005, Research } \\
\text { Policy }\end{array}$ & 1143 & Yes \\
\hline 8 & $\begin{array}{c}\text { More evolution than revolution: } \\
\text { Transition management in public } \\
\text { policy }\end{array}$ & $\begin{array}{l}\text { Rotmans J., Kemp R., Van } \\
\text { Asselt M., 2001, Foresight }\end{array}$ & 1122 & Yes \\
\hline 9 & $\begin{array}{c}\text { The multi-level perspective on } \\
\text { sustainability transitions: } \\
\text { Responses to seven criticisms }\end{array}$ & $\begin{array}{c}\text { Geels F.W., 2011, } \\
\text { Environmental Innovation } \\
\text { and Societal Transitions }\end{array}$ & 1089 & \\
\hline 10 & $\begin{array}{c}\text { Analyzing the functional } \\
\text { dynamics of technological } \\
\text { innovation systems: A scheme of } \\
\text { analysis }\end{array}$ & $\begin{array}{c}\text { Bergek A., Jacobsson S., } \\
\text { Carlsson B., Lindmark S., } \\
\text { Rickne A., 2008, Research } \\
\text { Policy }\end{array}$ & 982 & Yes \\
\hline 11 & $\begin{array}{l}\text { On the nature, function and } \\
\text { composition of technological } \\
\text { systems }\end{array}$ & $\begin{array}{c}\text { Carlsson B., Stankiewicz R., } \\
\text { 1991, Journal of Evolutionary } \\
\text { Economics }\end{array}$ & 982 & Yes \\
\hline 12 & $\begin{array}{c}\text { Strategic niche management and } \\
\text { sustainable innovation journeys: } \\
\text { Theory, findings, research } \\
\text { agenda, and policy }\end{array}$ & $\begin{array}{c}\text { Schot J., Geels F.W., 2008, } \\
\text { Technology Analysis and } \\
\text { Strategic Management }\end{array}$ & 926 & \\
\hline 13 & $\begin{array}{l}\text { Innovation studies and } \\
\text { sustainability transitions: The } \\
\text { allure of the multi-level } \\
\text { perspective and its challenges }\end{array}$ & $\begin{array}{l}\text { Smith A., Voß J.-P., Grin J., } \\
\text { 2010, Research Policy }\end{array}$ & 846 & \\
\hline 14 & $\begin{array}{l}\text { Ontologies, socio-technical } \\
\text { transitions (to sustainability), } \\
\text { and the multi-level perspective }\end{array}$ & $\begin{array}{c}\text { Geels F.W., 2010, Research } \\
\text { Policy }\end{array}$ & 778 & \\
\hline 15 & $\begin{array}{l}\text { Transition management for } \\
\text { sustainable development: A } \\
\text { prescriptive, complexity-based } \\
\text { governance framework }\end{array}$ & $\begin{array}{l}\text { Loorbach D., 2010, } \\
\text { Governance }\end{array}$ & 743 & \\
\hline 16 & $\begin{array}{l}\text { Regime Resistance against } \\
\text { Low-Carbon Transitions: } \\
\text { Introducing Politics and Power } \\
\text { into the Multi-Level Perspective }\end{array}$ & $\begin{array}{l}\text { Geels F.W., 2014, Theory, } \\
\text { Culture \& Society }\end{array}$ & 648 & \\
\hline 17 & $\begin{array}{l}\text { CAUTION! Transitions ahead: } \\
\text { Politics, practice, and sustainable } \\
\text { transition management }\end{array}$ & $\begin{array}{c}\text { Shove E., Walker G., 2007, } \\
\text { Environment and Planning A }\end{array}$ & 624 & Yes \\
\hline 18 & $\begin{array}{l}\text { Technological innovation } \\
\text { systems and the multi-level } \\
\text { perspective: Towards an } \\
\text { integrated framework }\end{array}$ & $\begin{array}{l}\text { Markard J., Truffer B., 2008, } \\
\text { Research Policy }\end{array}$ & 622 & Yes \\
\hline 19 & $\begin{array}{l}\text { Toward a spatial perspective on } \\
\text { sustainability transitions }\end{array}$ & $\begin{array}{l}\text { Coenen L., Benneworth P., } \\
\text { Truffer B., 2012, Research } \\
\text { Policy }\end{array}$ & 566 & \\
\hline
\end{tabular}


Table A1. Cont.

\begin{tabular}{|c|c|c|c|c|}
\hline No & Title & Authors, Year, and Journal & Citations & Markard et al., 2012 \\
\hline 20 & $\begin{array}{l}\text { What about the politics? } \\
\text { Sustainable development, } \\
\text { transition management, and } \\
\text { long-term energy transitions }\end{array}$ & $\begin{array}{l}\text { Meadowcroft J., 2009, Policy } \\
\text { Sciences }\end{array}$ & 521 & \\
\hline 21 & $\begin{array}{l}\text { Why are institutions the 'carriers } \\
\text { of history'?: Path dependence } \\
\text { and the evolution of conventions, } \\
\text { organizations and institutions }\end{array}$ & $\begin{array}{c}\text { David P.A., 1994, Structural } \\
\text { Change and Economic } \\
\text { Dynamics }\end{array}$ & 499 & \\
\hline 22 & $\begin{array}{l}\text { Growing grassroots innovations: } \\
\text { Exploring the role of } \\
\text { community-based initiatives in } \\
\text { governing sustainable energy } \\
\text { transitions }\end{array}$ & $\begin{array}{c}\text { Seyfang G., Haxeltine A., } \\
\text { 2012, Environment and } \\
\text { Planning C: Government and } \\
\text { Policy }\end{array}$ & 466 & \\
\hline 23 & $\begin{array}{c}\text { Transforming the energy sector: } \\
\text { The evolution of technological } \\
\text { systems in renewable energy } \\
\text { technology }\end{array}$ & $\begin{array}{c}\text { Jacobsson S., Bergek A., 2004, } \\
\text { Industrial and Corporate } \\
\text { Change }\end{array}$ & 445 & Yes \\
\hline 24 & $\begin{array}{l}\text { Can cities shape socio-technical } \\
\text { transitions and how would we } \\
\text { know if they were? }\end{array}$ & $\begin{array}{l}\text { Hodson M., Marvin S., 2010, } \\
\text { Research Policy }\end{array}$ & 438 & \\
\hline 25 & $\begin{array}{l}\text { A socio-technical analysis of } \\
\text { low-carbon transitions: } \\
\text { introducing the multi-level } \\
\text { perspective into transport } \\
\text { studies }\end{array}$ & $\begin{array}{l}\text { Geels F.W., 2012, Journal of } \\
\text { Transport Geography }\end{array}$ & 431 & \\
\hline 26 & $\begin{array}{l}\text { Processes and patterns in } \\
\text { transitions and system } \\
\text { innovations: Refining the } \\
\text { co-evolutionary multi-level } \\
\text { perspective }\end{array}$ & $\begin{array}{c}\text { Geels F.W., 2005, } \\
\text { Technological Forecasting } \\
\text { and Social Change }\end{array}$ & 428 & Yes \\
\hline 27 & $\begin{array}{l}\text { The dynamics of transitions in } \\
\text { socio-technical systems: A } \\
\text { multi-level analysis of the } \\
\text { transition pathway from } \\
\text { horse-drawn carriages to } \\
\text { automobiles (1860-1930) }\end{array}$ & $\begin{array}{c}\text { Geels Ir.F.W., 2005, } \\
\text { Technology Analysis and } \\
\text { Strategic Management }\end{array}$ & 422 & \\
\hline 28 & $\begin{array}{l}\text { Transition management as a } \\
\text { model for managing processes of } \\
\text { co-evolution towards sustainable } \\
\text { development }\end{array}$ & $\begin{array}{l}\text { Kemp R., Loorbach D., } \\
\text { Rotmans J., 2007, } \\
\text { International Journal of } \\
\text { Sustainable Development } \\
\text { and World Ecology }\end{array}$ & 420 & \\
\hline
\end{tabular}

Note about the table: this list includes both papers included in Markard et al. (2012) as well as new ones. Because some papers have gained additional citations since 2012, the list also includes papers older than 2010.

\section{References}

1. Markard, J.; Raven, R.; Truffer, B. Sustainability transitions: An emerging field of research and its prospects. Res. Policy 2012, 41, 955-967. [CrossRef]

2. European Environment Agency. SOER 2015-The European Environment-State and Outlook 2015, SOER 2015. Available online: https:/ / www.eea.europa.eu/soer/2015 (accessed on 13 January 2022).

3. Bui, S.; Cardona, A.; Lamine, C.; Cerf, M. Sustainability transitions: Insights on processes of niche-regime interaction and regime reconfiguration in agri-food systems. J. Rural. Stud. 2016, 48, 92-103. [CrossRef]

4. Planko, J.; Cramer, J.M.; Chappin, M.M.; Hekkert, M.P. Strategic collective system building to commercialize sustainability innovations. J. Clean. Prod. 2016, 112, 2328-2341. [CrossRef]

5. European Environmental Agency. Perspectives on Transitions to Sustainability; Publications Office of the European Union: Luxemburg, 2018. Available online: https://www.eea.europa.eu/publications/perspectives-on-transitions-to-sustainability (accessed on 13 January 2022). 
6. Geels, F.W. Technological transitions as evolutionary reconfiguration processes: A multi-level perspective and a case-study. Res. Policy 2002, 31, 1257-1274. [CrossRef]

7. Kemp, R.; Schot, J.; Hoogma, R. Regime shifts to sustainability through processes of niche formation: The approach of strategic niche management. Technol. Anal. Strateg. Manag. 1998, 10, 175-198. [CrossRef]

8. Hekkert, M.P.; Suurs, R.A.A.; Negro, S.O.; Kuhlmann, S.; Smits, R.E.H.M. Functions of innovation systems: A new approach for analysing technological change. Technol. Forecast. Soc. Chang. 2007, 74, 413-432. [CrossRef]

9. Rip, A.; Kemp, R. Technological change. In Human Choice and Climate Change; Rayner, S., Malone, E.L., Eds.; Battelle Press: Columbus, OH, USA, 1998; pp. 327-399.

10. Van Driel, H.; Schot, J. Radical Innovation as a Multilevel Process: Introducing Floating Grain Elevators in the Port of Rotterdam. Technol. Cult. 2005, 46, 51-76. [CrossRef]

11. Geels, F.W.; Kern, F.; Fuchs, G.; Hinderer, N.; Kungl, G.; Mylan, J.; Neukirch, M.; Wassermann, S. The enactment of socio-technical transition pathways: A reformulated typology and a comparative multi-level analysis of the German and UK low-carbon electricity transitions (1990-2014). Res. Policy 2016, 45, 896-913. [CrossRef]

12. Geels, F.W.; Verhees, B. Cultural legitimacy and framing struggles in innovation journeys: A cultural-performative perspective and a case study of Dutch nuclear energy (1945-1986). Technol. Forecast. Soc. Chang. 2011, 78, 910-930. [CrossRef]

13. Bohr, J.; Dunlap, R.E. Key Topics in environmental sociology, 1990-2014: Results from a computational text analysis. Environ. Sociol. 2018, 4, 181-195. [CrossRef]

14. Athey, S.; Imbens, G.W. Machine learning methods that economists should know about. Annu. Rev. Econ. 2019, 11, 685-725. [CrossRef]

15. Gentzkow, M.; Kelly, B.; Taddy, M. Text as data. J. Econ. Lit. 2019, 57, 535-574. [CrossRef]

16. Blei, D.M.; Lafferty, J.D. A correlated topic model of science. Ann. Appl. Stat. 2007, 1, 17-35. [CrossRef]

17. Roberts, M.E.; Stewart, B.M.; Tingley, D. Stm: An R package for structural topic models. J. Stat. Softw. 2019, 91, 1-40. [CrossRef]

18. Lindstedt, N.C. Structural Topic Modeling for Social Scientists: A Brief Case Study with Social Movement Studies Literature, 2005-2017. Soc. Curr. 2019, 6, 307-318. [CrossRef]

19. Csardi, G.; Nepusz, T. The igraph software package for complex network research. Int. J. Complex Syst. 2006, 1695, 1-9.

20. Bischof, J.; Airoldi, E.M. Summarizing topical content with word frequency and exclusivity. In Proceedings of the 29th International Conference on Machine Learning (ICML-12), Edinburgh, UK, 26 June-1 July 2012; pp. $201-208$.

21. Avelino, F. Theories of power and social change. Power contestations and their implications for research on social change and innovation. J. Political Power 2021, 14, 425-448. [CrossRef]

22. Görg, C.; Brand, U.; Haberl, H.; Hummel, D.; Jahn, T.; Liehr, S. Challenges for Social-Ecological Transformations: Contributions from Social and Political Ecology. Sustainability 2017, 9, 1045. [CrossRef]

23. Grenni, S.; Soini, K.; Horlings, L.G. The inner dimension of sustainability transformation: How sense of place and values can support sustainable place-shaping. Sustain. Sci. 2020, 15, 411-422. [CrossRef]

24. Woiwode, C.; Schäpke, N.; Bina, O.; Veciana, S.; Kunze, I.; Parodi, O.; Schweizer-Ries, P.; Wamsler, C. Inner transformation to sustainability as a deep leverage point: Fostering new avenues for change through dialogue and reflection. Sustain. Sci. 2021, 16, 841-858. [CrossRef]

25. Yunus, M.; Biggeri, M.; Testi, E. Social Economy and Social Business Supporting Policies for Sustainable Human Development in a Post-COVID-19 World. Sustainability 2021, 13, 12155. [CrossRef]

26. Sen, A.K. Development as Freedom; Oxford University Press: New Delhi, India, 1999.

27. Schwab, K.; Vanham, P. Stakeholder Capitalism: A Global Economy That Works for Progress, People and Planet; John Wiley \& Sons Inc: Hoboken, NJ, USA, 2021.

28. Feola, G.; Koretskaya, O.; Moore, D. (Un) making in sustainability transformation beyond capitalism. Glob. Environ. Chang. 2021, 69, 102290. [CrossRef]

29. Goetz, A.; Gotchev, B.; Richter, I.; Nicolaus, K. Introduction to the special issue: Reform or revolution? What is at stake in democratic sustainability transformations. Sustain. Sci. Pract. Policy 2020, 16, 335-352. [CrossRef]

30. Clark, D.A.; Biggeri, M.; Frediani, A.A. Participation, empowerment and capabilities: Key lessons and future challenges. In The Capability Approach, Empowerment and Participation; Clark, D.A., Biggeri, M., Frediani, A.A., Eds.; Palgrave Macmillan: London, UK, 2019; pp. 385-402.

31. Mori, T.; Tasaki, T. Factors influencing pro-environmental collaborative collective behaviors toward sustainability transition-A case of renewable energy. Environ. Educ. Res. 2019, 25, 566-584. [CrossRef]

32. Ferguson, R.; Lovell, S. Grassroots engagement with transition to sustainability: Diversity and modes of participation in the international permaculture movement. Ecol. Soc. 2015, 20, 39. [CrossRef]

33. Dinnie, E.; Holstead, K.L. The influence of public funding on community-based sustainability projects in Scotland. Environ. Innov. Soc. Transit. 2018, 29, 25-33. [CrossRef]

34. Sloot, D.; Jans, L.; Steg, L. In it for the money, the environment, or the community? Motives for being involved in community energy initiatives. Glob. Environ. Chang. 2019, 57, 101936. [CrossRef]

35. Creamer, E.; Allen, S.; Haggett, C. 'Incomers' leading 'community-led' sustainability initiatives: A contradiction in terms? Environ. Plan. C Politics Space 2019, 37, 946-964. [CrossRef] 
36. Tourais, P.; Videira, N. A participatory systems mapping approach for sustainability transitions: Insights from an experience in the tourism sector in Portugal. Environ. Innov. Soc. Transit. 2021, 38, 153-168. [CrossRef]

37. Bohunovsky, L.; Jäger, J.; Omann, I. Participatory scenario development for integrated sustainability assessment. Reg. Environ. Change 2011, 11, 271-284. [CrossRef]

38. Brundiers, K.; Wiek, A.; Kay, B. The Role of Transacademic Interface Managers in Transformational Sustainability Research and Education. Sustainability 2013, 5, 4614-4636. [CrossRef]

39. Kioupi, V.; Voulvoulis, N. Education for Sustainable Development: A Systemic Framework for Connecting the SDGs to Educational Outcomes. Sustainability 2019, 11, 6104. [CrossRef]

40. Rogge, K.S.; Schleich, J. Do policy mix characteristics matter for low-carbon innovation? A survey-based exploration of renewable power generation technologies in Germany. Res. Policy 2018, 47, 1639-1654. [CrossRef]

41. Nykamp, H. Policy Mix for a Transition to Sustainability: Green Buildings in Norway. Sustainability 2020, 12, 446. [CrossRef]

42. Mavrot, C.; Hadorn, S.; Sager, F. Mapping the mix: Linking instruments, settings and target groups in the study of policy mixes. Res. Policy 2019, 48, 103614. [CrossRef]

43. Hernández, A.L.G.; Bolwig, S.; Hansen, U.E. When policy mixes meet firm diversification: Sugar-industry investment in bagasse cogeneration in Mexico (2007-2020). Energy Res. Soc. Sci. 2021, 79, 102171. [CrossRef]

44. Edsand, H.-E. Technological innovation system and the wider context: A framework for developing countries. Technol. Soc. 2019, 58, 101150. [CrossRef]

45. Gota, S.; Huizenga, C.; Peet, K.; Medimorec, N.; Bakker, S. Decarbonising transport to achieve Paris Agreement targets. Energy Effic. 2019, 12, 363-386. [CrossRef]

46. Lomax, G.; Workman, M.; Lenton, T.; Shah, N. Reframing the policy approach to greenhouse gas removal technologies. Energy Policy 2015, 78, 125-136. [CrossRef]

47. Fridahl, M. Socio-political prioritization of bioenergy with carbon capture and storage. Energy Policy 2017, 104, 89-99. [CrossRef]

48. Goh, T.; Ang, B.W.; Su, B.; Wang, H. Drivers of stagnating global carbon intensity of electricity and the wat forward. Energy Policy 2018, 113, 149-156. [CrossRef]

49. Vergragt, P.J.; Markusson, N.; Karlsson, H. Carbon capture and storage, bio-energy with carbon capture and storage, and the escape from the fossil-fuel lock-in. Glob. Environ. Chang. 2011, 21, 282-292. [CrossRef]

50. Mathews, J.A. The renewable energies technology surge: A new techno-economic paradigm in the making? Futures 2013, 46 , 10-22. [CrossRef]

51. Chen, X.; Li, Z.; Gallagher, K.P.; Mauzerall, D.L. Financing carbon lock-in in developing countries: Bilateral financing for power generation technologies from China, Japan, and the United States. Appl. Energy 2021, 300, 117318. [CrossRef]

52. Li, A.; Xu, Y.; Shiroyama, H. Solar lobby and energy transition in Japan. Energy Policy 2019, 134, 110950. [CrossRef]

53. Norberto, C.; Gonzalez-Brambila, C.N.; Matsumoto, Y. Systematic analysis of factors affecting solar PV deployment. J. Energy Storage 2016, 6, 163-172. [CrossRef]

54. Csereklyei, Z.; Anantharama, N.; Kallies, A. Electricity market transitions in Australia: Evidence using model-based clustering. Energy Econ. 2021, 103, 105590. [CrossRef]

55. Pai, S.; Zerriffi, H.; Jewell, J.; Pathak, J. Solar has greater techno-economic resource suitability than wind for replacing coal mining jobs. Environ. Res. Lett. 2020, 15, 034065. [CrossRef]

56. Healy, N.; Barry, J. Politicizing energy justice and energy system transitions: Fossil fuel divestment and a "just transition". Energy Policy 2017, 108, 451-459. [CrossRef]

57. Williams, S.; Doyon, A. The Energy Futures Lab: A case study of justice in energy transitions. Environ. Innov. Soc. Transit. 2020, 37, 290-301. [CrossRef]

58. Lyytimäki, J. Renewable energy in the news: Environmental, economic, policy and technology discussion of biogas. Sustain. Prod. Consum. 2018, 15, 65-73. [CrossRef]

59. Lyytimäki, J.; Nygrén, N.A.; Pulkka, A.; Rantala, S. Energy transition looming behind the headlines? Newspaper coverage of biogas production in Finland. Energ. Sustain. Soc. 2018, 8, 15. [CrossRef]

60. Antal, M.; Karhunmaa, K. The German energy transition in the British, Finnish and Hungarian news media. Nat. Energy 2018, 3, 994-1001. [CrossRef]

61. Haukkala, T. A struggle for change-The formation of a green-transition advocacy coalition in Finland. Environ. Innov. Soc. Transit. 2018, 27, 146-156. [CrossRef]

62. Wadin, J.L.; Ahlgren, K.; Bengtsson, L. Joint business model innovation for sustainable transformation of industries-A large multinational utility in alliance with a small solar energy company. J. Clean. Prod. 2017, 160, 139-150. [CrossRef]

63. Kishna, M.; Niesten, E.; Negro, S.; Hekkert, M.P. The role of alliances in creating legitimacy of sustainable technologies: A study on the field of bio-plastics. J. Clean. Prod. 2017, 155, 7-16. [CrossRef]

64. Laukkanen, M.; Patala, S. Analysing barriers to sustainable business model innovations: Innovation systems approach. Int. J. Innov. Manag. 2014, 18, 1440010. [CrossRef]

65. van Mierlo, B. Convergent and divergent learning in photovoltaic pilot projects and subsequent niche development. Sustain. Sci. Pract. Policy 2012, 8, 4-18. [CrossRef]

66. Kuokkanen, A.; Nurmi, A.; Mikkilä, M.; Kuisma, M.; Kahiluoto, H.; Linnanen, L. Agency in regime destabilization through the selection environment: The Finnish food system's sustainability transition. Res. Policy 2018, 47, 1513-1522. [CrossRef] 
67. Duygan, M.; Stauffacher, M.; Meylan, G. A heuristic for conceptualizing and uncovering the determinants of agency in sociotechnical transitions. Environ. Innov. Soc. Transit. 2019, 33, 13-29. [CrossRef]

68. van Doren, D.; Runhaar, H.; Raven, R.P.; Giezen, M.; Driessen, P.P. Institutional work in diverse niche contexts: The case of low-carbon housing in the Netherlands. Environ. Innov. Soc. Transit. 2020, 35, 116-134. [CrossRef]

69. Runhaar, H.; Fünfschilling, L.; Dasselaar, A.va.; Moors, E.H.; Temmink, R.; Hekkert, M. Endogenous regime change: Lessons from transition pathways in Dutch dairy farming. Environ. Innov. Soc. Transit. 2020, 36, 137-150. [CrossRef]

70. Levidow, L.; Upham, P. Linking the multi-level perspective with social representations theory: Gasifiers as a niche innovation reinforcing the energy-from-waste (EfW) regime. Technol. Forecast. Soc. Chang. 2017, 120, 1-13. [CrossRef]

71. Ford, A.; Newell, P. Regime resistance and accommodation: Toward a neo-Gramscian perspective on energy transitions. Energy Res. Soc. Sci. 2021, 79, 102163. [CrossRef]

72. Puech, C.; Brulaire, A.; Paraiso, J.; Faloya, V. Collective design of innovative agroecological cropping systems for the industrial vegetable sector. Agric. Syst. 2021, 191, 103153. [CrossRef]

73. Aare, A.K.; Lund, S.; Hauggaard-Nielsen, H. Exploring transitions towards sustainable farming practices through participatory research-The case of Danish farmers' use of species mixtures. Agric. Syst. 2021, 189, 103053. [CrossRef]

74. Meynard, J.-M.; Charrier, F.; le Bail, M.; Magrini, M.-B.; Charlier, A.; Messéan, A. Socio-technical lock-in hinders crop diversification in France. Agron. Sustain. Dev. 2018, 38, 1-13. [CrossRef]

75. Messner, R.; Johnson, H.; Richards, C. From surplus-to-waste: A study of systemic overproduction, surplus and food waste in horticultural supply chains. J. Clean. Prod. 2021, 278, 123952. [CrossRef]

76. Aare, A.K.; Egmose, J.; Lund, S.; Hauggaard-Nielsen, H. Opportunities and barriers in diversified farming and the use of agroecological principles in the Global North-The experiences of Danish biodynamic farmers. Agroecol. Sustain. Food Syst. 2021, 45, 390-416. [CrossRef]

77. Stratton, A.E.; Wittman, H.; Blesh, J. Diversification supports farm income and improved working conditions during agroecological transitions in southern Brazil. Agron. Sustain. Dev. 2021, 41, 1-22. [CrossRef]

78. Lamine, C. Transition pathways towards a robust ecologization of agriculture and the need for system redesign. Cases from organic farming and IPM. J. Rural. Stud. 2011, 27, 209-219. [CrossRef] 